\title{
STYGMATY BÓLU PSYCHICZNEGO U CZYTELNIKA... CZYLI ROZMYŚLANIA HISTORYKA O KSIAZŻCE ADELI MONIETY „STYGMATY BÓLU PSYCHICZNEGO U SYBIRAKÓW" 1
}

Na początek ważna uwaga metodologiczna. Praca Adeli Moniety nie jest książką naukową, choć na taką ma niewątpliwie wyglądać. Nie jest książką naukową, gdyż nie ına w niej nic, co tożsame jest z określeniem „praca naukowa”. Jest to ogromny, bałaganiarski zbiór przeróżnych wspomnień, relacji i wierszy podzielony licznymi wtrętami narratora, którym jest autorka, ułożony na chybił trafił bez logicznego założenia i potrzeby udowodnienia jakiejś tezy. Dodatkowo zawiera ona tak ogromną ilość błędów merytorycznych, rzeczowych, składniowych, fleksyjnych, ortograficznych i gramatycznych, iż dyskwalifikuje ją to jako pracę mającą pomóc młodemu pokoleniu w zrozumieniu, czyın było zesłanie w życiu setek tysięcy obywateli polskich. Jedynym elementem broniącym książkę przed natychmiastowym skierowaniem jej na przemiał są zamieszczone tam wspomnienia. Reszta powinna zostać gruntownie poprawiona, a właściwie usunięta.

Dla opisania tragedii zesłania tkwiącej do dziś w ludziach wystarczą ich wspomnienia, listy, krótkie zdania, wiersze lub zdjęcia. Nie trzeba udowadniać, że ludziom tym na zesłaniu wyrządzono ogromną krzywdę psychiczną, która na zawsze pozostała w ich pamięci, zwłaszcza, że większość piszących dziś wspomnienia doświadczyła "Sybiru” jako dzieci, które przeszły wyjątkowo szybką i bolesną szkołę życia. O tym, że ludzie, którzy przeżyli obozy koncentracyjne, lagry, zesłanie, czy getto do dziś cierpią z tego powodu wiadomo od dawna. Wystarczy zapoznać się z obszerną literaturą na ten temat. Jeśli zaś naprawdę autorka chciała pokazać „stygmaty bólu psychicznego" u ludzi poddanych działaniu bodźców ekstremalnych i zdiagnozowanych ja-

1 Adela Monieta, Stygmaty bólu psychicznego u Sybiraków, Wydawnictwo „BUK”, Białystok 2004. 
ko PTSD, powinna (obowiązkowo, moim zdaniem) przybliżyć czytelnikom problemy, z którymi borykają się dziś liczne szpitale w Izraelu, gdzie tysiące osób, które przeżyły zagładę, stanowi „namacalny” i wyjątkowo wstrząsający dowód założonych w tytule tez.

Ponieważ recenzowanie tej pracy w zasadzie sprowadza się do wyliczania błędów, zaś to oznaczałoby napisanie kolejnego rozdziału, poprzestanę na skorygowaniu „wpadek” szczególnie rażących. Już na wstępie zaskoczyło mnie następujące zdanie: „Modus vivendi ofiar z życia obozów koncentracyjnych poddano wcześniej opracowaniom zarówno historycznym, jak i psychologiczno-medycznym ze względu na sprzyjające uwarunkowania w kraju". O co tak naprawdę chodziło w tym miejscu autorce - nie udało mi się pojąć. Poradziłem się znajomego lekarza, bo może nie rozumiem języka współczesnej psychiatrii i psychologii klinicznej, ale także on bezradnie rozłożył ręce. Nadal nie wiem, jak można „modus vivendi ofiar” poddać opracowaniom historycznym. Różne rzeczy zdarzało mi się poddawać ocenie historycznej, ale jeśli już mam oceniać „sposób na życie”, to raczej z perspektywy historycznej oceny życia codziennego ludzi na zesłaniu. Rzecz to bardzo ciekawa i już przez niektórych autorów wykorzystana do opisu zesłańczej codzienności, m.in. w Kazachstanie, jednak nikt jeszcze nie używał tego instrumentu badawczego w ten sposób.

Dalej jest coraz gorzej, zaś język używany przez autorkę staje się kompletnie nieczytelny. Pomijam już taki drobiazg, że Antoni Kuczyński nie napisał żadnej pracy pt. „Syberia”, na którą powołuje się autorka. Jedyna znana mi praca tego autora o podobnie brzmiącym tytule to Syberia. Czterysta lat polskiej diaspory wydana kilka lat temu we Wrocławiu. Poza tym, co w pracy naukowej jest bezwzględnie wymagane, autorka powinna wiedzieć, że jeśli się coś cytuje, to powinno się podać pełny tytuł pracy, miejsce i rok wydania oraz koniecznie [sic!] strony, z których się przepisało dany fragment.

Pewnym novum dla mnie, jako badacza problemu zsyłki, jest przyjęta przez autorkę teza, że „Sybirakami” byli wyłącznie Polacy. O ile mnie pamięć nie myli w latach 1939-1941 mieliśmy do czynienia z masowymi deportacjami obywateli polskich wszystkich narodowości zamieszkujących ówczesne ziemie II RP. Nie było też żadnych masowych deportacji Polaków w latach pięćdziesiątych, przynajmniej na terenach II RP pozostawionych przy Polsce. Po drugiej stronie granicy „narodowe” w formie represje dotykały głównie byłych żołnierzy walczących w szeregach Polskich Sił Zbrojnych na zachodzie, tzw. andersowców oraz osób buntujących się przeciwko przymusowej kolektywizacji gospodarstw rolnych. 
Pragnę też przypomnieć autorce, że jej główna teza przyjęta w pierwszym rozdziale (, założeniem egzystencjalizmu jest fakt, iż pewne własności rzeczy wynikają z ich istoty, czyli ogólna ich istota decyduje o ich konkretnym istnieniu; inaczej ich esencja stanowi o ich egzystencji") dotycząca filozoficznego pojęcia egzystencjalizmu świadczy dobitnie o tym, że albo nie przeczytała ona nigdy tego fragmentu pracy Tatarkiewicza, albo nagina fakty do wygodnych dla siebie tez. Gdyby tam zajrzała, odkryłaby, że egzystencjaliści całkowicie negowali postawioną wyżej tezę głosząc, iż „esencja nie stanowi o egzystencji, nie wyprzedza egzystencji. Bo nie ma $\mathrm{w}$ ogóle esencji" (Władysław Tatarkiewicz, Historia filozofi, t. III, Warszawa 1968, s. 364). Tyle, jeśli chodzi o kwestie filozoficzne.

Co do spraw historycznych: nieprawdą jest istnienie masowego, zorganizowanego poboru do Armii Czerwonej w pierwszym roku okupacji radzieckiej. Są dziś znane dokumenty jednoznacznie to udowadniające, a jeśli już werbowano kogoś do wojska, to była to raczej młodzież białoruska, bardziej bezpieczna ideowo i politycznie od Polaków. Obywatelstwo nie może „obowiązywać”, może zostać przyjęte lub narzucone. Zaś przymusowa paszportyzacja nie objęła całej ludności, gdyż nie to było jej celem. Nie objęła także wszystkich osób, których dotyczyła, bo zabrakło paszportów, czasu, pieniędzy i papieru fotograficznego, by zrobić stosowne zdjęcie. Agresja sowiecka nie przyjęła żadnego imperialnego charakteru. Autorka najwyrá́niej nie rozumie tych pojęć. Nie stanowiła też „elementów realizacji planu światowej rewolucji komunistycznej". Plany rozszerzenia radzieckiej strefy wpływów były, jednak nie za pomocą rewolucji. Stalin czekał na wojnę pomiędzy „imperialnymi” państwami zachodnimi, która miała mu pomóc: w „eksporcie rewolucji na bagnetach sowieckich żołnierzy". W pierwszych miesiącach okupacji nie odbywały się żadne masowe rewizje w domach i mieszkaniach. Terror dotyczył wszystkich, którzy stanowili realne lub domniemane zagrożenia dla państwa radzieckiego, zaś „maltretowanie” aresztowanych, mające na celu zmuszenie ich do przyznania się do winy, było „naturalną” koleją rzeczy wynikającą z obowiązującej wówczas doktryny prawnej zakładającej, że winnym jest ten, kto się do winy przyzna nawet, jeśli na jego winę nie ma żadnych dowodów. Tortury miały „pomóc” aresztowanemu przyznać się do winy, co praktycznie zamykało całe śledztwo.

Nie wiem, skąd autorka wzięła wielokilometrowe marsze [s. 19]. Czy chodzi jej o „drogi śmierci” latem 1941 r., czy też końcowe etapy podróży na zesłanie? Bo o wielokilometrowych marszach pomiędzy więzieniami nie słyszałem. Wiosną 1940 roku, na podstawie decyzji Biura Politycznego z 5 marca 1940 r. zgladzono nie 15 a co najmniej 21 tys. ludzi. Armia 
Czerwona nie mordowała masowo kobiet i dzieci. Nie czyniło tego także NKWD. Można obu tym służbom zarzucać wiele bestialskich zachowań, ale trzeba znać umiar. Nie było też żadnych masowych morderstw księży katolickich i prawosławnych. Najwyższe czynniki decyzyjne w Mińsku zalecały wręcz powstrzymywanie się od zbyt drastycznych form nacisku na kler, zwłaszcza katolicki, by nie zrażać do siebie lokalnych społeczności, zwłaszcza wiejskich.

Należy także raz na zawsze skończyć z tezą o milionach ludzi deportowanych w głąb ZSRR w latach 1939-1941. Dziś już w miarę dokładnie wiemy ile osób deportowano, znamy numery transportów, znamy miejsca docelowe, potrafimy nawet stworzyć pierwsze imienne zestawienia zesłańców (np. deportowanych $\mathrm{z}$ obwodu białostockiego i przebywających obwodzie archangielskimi - zob. XIV tom Indeksu Represjonowanych wydany przez Ośrodek KAR'TA w Warszawie w 2004 r.). Pisanie o milionach ludzi i zestawianie tego z tezą, że do kraju powróciło ok. 500 tys. osób jest naginaniem historii do własnych, partykularnych celów. Poza tym autorka kompletnie nie panuje nad warsztatem. Doprawdy nie mam pojęcia skąd wzięła tę liczbę. Nie da się jej praktycznie udowodnić. Znamy dokładnie liczbę Polaków i Żydów, którym udało się powrócić do kraju z głębi ZSRR w latach 1945-46 oraz w czasie drugiej fali repatriacji w latach 1953-56. Nigdy nie było ich pół miliona. Przydałyby się w tym miejscu gruntowne korepetycje $\mathrm{z}$ historii.

Dalej jest tylko gorzej. Widok jednostronicowego [sic!] rozdziału II całkowicie mnie zaskoczył. Widziałem już różne rzeczy, ale czegoś takiego nigdy. Także opracowanie redakcyjne relacji i wspomnień stoi na rozpaczliwie niskim poziomie edytorskim. W tekstach roi się od przepuszczonych błędów gramatycznych, stylistycznych i ortograficznych. Co ciekawsze osobiście znam wiele osób, których wspomnienia zamieściła autorka. Wielu z tych ludzi udzieliło mi w przeszłości obszernych relacji. Mam je w domu i wiem, jaki był ich poziom. 'To, co dostajemy na kartach książki świadczy o tym, że autorka nie zadała sobie żadnego trudu opracowania relacji, wygładzenia ich, poprawienia oczywistych błędów wynikających z zawodności ludzkiej pamięci.

Rzeczą naganną jest też przedrukowywanie przez autorkę fragmentów wydanych wcześniej książek (m.in. Marii Niewińskiej, Sławomira Rawicza, Janusza Rautuszko, Urszuli Muskul, 'Teofila Mikulskiego, Wincentego Kwapiszewskiego, Barbary Piotrowskiej-Dubik) bez podania miejsca wydania oraz stron, które są cytowane nawet, jeśli na końcu książki zamieszczona została niewielka bibliografia. Autorka pracy wyjątkowo „swobodnie” dobiera 
sobie fragmenty $\mathrm{z}$ tych książek bez wyraźnego zaznaczania gdzie kończy się jeden, a gdzie zaczyna drugi. W efekcie powstaje coś, co nie ma nic wspólnego $\mathrm{z}$ pierwotną pracą.

$\mathrm{Na}$ temat rozdziału piątego mogę powiedzieć tylko jedno - to wielkie nieporozumienie. Zupełnie nie wiem, po co on powstal i o co autorce chodziło. Błagam też o wyjaśnienie pojęcia ,pamięć reprodukowana w różnych formach"

Pozostaje do omówienia jeszcze jedna rzecz. Zamieszczony na końcu książki wykaz skrótów. Tego się nie da ocenić żadnymi cenzuralnymi słowami. Aby nie być gołosłownym kilka „wiekopomnych odkryć" autorki: KGB - to Komitet Bezpieczeístwa Narodowego; szkoda, że Pani ta zapomniała, co znaczy słowo „gosudarstwiennoj”. KPZ - to Wstępne Biuro Śledcze; tak naprawdę chodzi zaś o areszt śledczy ( „kamiera priedwaritielnogo zakliuczenija"). MGB - to Ministerstwo Bezpieczeístwa Publicznego, zaś POW - to Polski Oddział Wyzwoleńiczy [sic!]. Nawet dziecko w szkole podstawowej bez trudu rozszyfruje ten skrót. Co ciekawe skrót MSZ RF okazał się dla autorki zadaniem nie do pokonania. Śpieszę wyjaśnić, że chodzi o Ministerstwo Spraw Zagranicznych Federacji Rosyjskiej. Ale to jeszcze nie koniec. „Sielsowiety” - to „Posterunek NKWD”, „Smiersz” -- „Urząd do Walki ze Szpiegostwem”, zaś ZS -- „Związek Sowiecki”. Oznacza to, że od kilku lat jestem w posiadaniu Odznaki Honorowej Sybiraka nadanej mi przez Zarząd Główny Związku Sowieckiego. To chyba powinno wystarczyć za cały komentarz do poziomu prezentowanej pracy.

Podsumowując rozważania na temat tej pracy mogę jedynie stwierdzić, że traumatyczne doświadczenia wynikłe $\mathrm{z}$ jej studiowania odbiły się $\mathrm{w}$ sposób zdecydowanie negatywny na moim zdrowiu. W kwestii stygmatów nie będę się wypowiadal i pozostawię to Kongregacji Nauki i Wiary, zaś książkę zostawię w domowej biblioteczce. Jej ponowna lektura będzie doskonałą pokutą, gdy zbytnio nagrzeszę. 